\title{
Rural policy, rural quangos - searching for clarity in West Dorset, south west England
}

\section{Commonwealth Journal of Local Governance}

Issue 20: December 2017

http://epress.lib.uts.edu.au/ojs/index.php/cjlg

\section{Gordon Morris}

Centre for Rural Policy Research

University of Exeter, and

Bournemouth University

United Kingdom

Email: g.r.morris@exeter.ac.uk grmmorris@btinternet.com

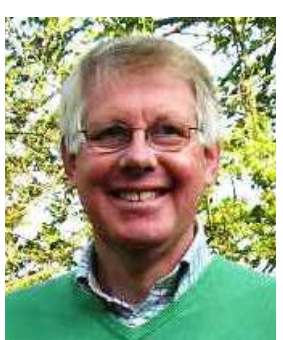

\begin{abstract}
The research discussed in this paper arose from the writer's interest in United Kingdom (UK) rural policy, government and governance. Its aims were to: 1) find out the extent to which the participants in the research, many of whom are involved in UK local government, were aware of the nongovernmental advisory and support organisations that, from 1909 until 2013, were involved with rural policy; and 2) establish the loci of influence in relation to aspects of rural policy. The data, gathered from interviews and an online questionnaire, suggests that political influence lies primarily with the Conservative Party, whose elected members run the district and county councils. Other sources of influence include the middle and landed classes. There is ambiguity, however. Some clerks and councillors admitted that they do not know where influence lies; suggesting that they, at least, do not believe it lies with them. Awareness of the organisations is unsurprisingly varied according to the participants' backgrounds. Overall, the data suggests that the more remote organisations were physically from 'work on the ground', and the more years that have passed since their closure, the lower the awareness of their existence and work.
\end{abstract}




\section{List of acronyms}

\begin{tabular}{|c|c|c|c|c|c|c|c|}
\hline ACRE & $\begin{array}{l}\text { Action for Communities in } \\
\text { Rural England }\end{array}$ & DCA & $\begin{array}{l}\text { Dorset Community } \\
\text { Action }\end{array}$ & $\mathrm{NE}$ & Natural England & RSN & $\begin{array}{l}\text { Rural Services } \\
\text { Network }\end{array}$ \\
\hline $\mathrm{CA}$ & Countryside Agency & DCC & $\begin{array}{l}\text { Dorset County } \\
\text { Council }\end{array}$ & NFU & $\begin{array}{l}\text { National Farmers' } \\
\text { Union }\end{array}$ & RSPB & $\begin{array}{l}\text { Royal Society for the } \\
\text { Protection of Birds }\end{array}$ \\
\hline CAll & Countryside Alliance & DLEP & $\begin{array}{l}\text { Dorset Local } \\
\text { Enterprise } \\
\text { Partnership }\end{array}$ & NHS & National Health Service & RSPCA & $\begin{array}{l}\text { Royal Society for the } \\
\text { Protection of Animals }\end{array}$ \\
\hline CBI & $\begin{array}{l}\text { Confederation of British } \\
\text { Industry }\end{array}$ & DWT & $\begin{array}{l}\text { Dorset Wildlife } \\
\text { Trust }\end{array}$ & NIMBY & 'Not in my backyard' & SWRDA & $\begin{array}{l}\text { South West Regional } \\
\text { Development Agency }\end{array}$ \\
\hline CLA & $\begin{array}{l}\text { Country Land and } \\
\text { Business Association }\end{array}$ & EA & $\begin{array}{l}\text { Environment } \\
\text { Agency }\end{array}$ & NT & National Trust & TCPA & $\begin{array}{l}\text { Town and Country } \\
\text { Planning Association }\end{array}$ \\
\hline $\mathrm{CoCo}$ & Countryside Commission & FSB & $\begin{array}{l}\text { Federation of Small } \\
\text { Businesses }\end{array}$ & POPP & $\begin{array}{l}\text { (Dorset's) Partnership } \\
\text { for Older People } \\
\text { Programme }\end{array}$ & UKIP & $\begin{array}{l}\text { United Kingdom } \\
\text { Independence Party }\end{array}$ \\
\hline CoSIRA & $\begin{array}{l}\text { Council for Small } \\
\text { Industries in Rural Areas }\end{array}$ & GP & $\begin{array}{l}\text { General Practitioner } \\
\text { (= community } \\
\text { doctor })\end{array}$ & Quango & $\begin{array}{l}\text { Quasi-autonomous } \\
\text { non-governmental } \\
\text { organisation }\end{array}$ & WDDC & $\begin{array}{l}\text { West Dorset District } \\
\text { Council }\end{array}$ \\
\hline CPRE & $\begin{array}{l}\text { Campaign to Protect Rural } \\
\text { England }\end{array}$ & IoD & $\begin{array}{l}\text { Institute of } \\
\text { Directors }\end{array}$ & RCPU & $\begin{array}{l}\text { Rural Communities } \\
\text { Policy Unit }\end{array}$ & WI & Women's Institute \\
\hline CRC & $\begin{array}{l}\text { Commission for Rural } \\
\text { Communities }\end{array}$ & LACS & $\begin{array}{l}\text { League Against } \\
\text { Cruel Sports }\end{array}$ & RDC & $\begin{array}{l}\text { Rural Development } \\
\text { Commission }\end{array}$ & & \\
\hline DAPTC & $\begin{array}{l}\text { Dorset Association of } \\
\text { Parish \& Town Councils }\end{array}$ & MEP & $\begin{array}{l}\text { Member of the } \\
\text { European } \\
\text { Parliament }\end{array}$ & RICS & $\begin{array}{l}\text { Royal Institution of } \\
\text { Chartered Surveyors }\end{array}$ & & \\
\hline DC & Development Commission & MP & $\begin{array}{l}\text { Member of } \\
\text { Parliament }\end{array}$ & RSA & Rural Shops Alliance & & \\
\hline
\end{tabular}

\section{Introduction}

This research has three aims: to find out 1) the extent to which the UK's Commission for Rural Communities $^{1}$ (CRC) and other now defunct rural organisations are remembered; 2) what people's concerns are about rural living; and 3) their opinions as to where influence over rural policies unrelated to land and landed interests lie.

The CRC was abolished in $2013^{2}$ (UK Government, 2013). Therefore, although the effects of its closure might be hard to discern, awareness of its existence and work should be relatively high, albeit its remit was essentially national, not local (Commission for Rural Communitees 2006a, p. 4). The practical 'on the ground' work done by the South West Regional Development Agency (SWRDA) effectively stopped in 2012, while the Rural Development Commission's Rural Development Programme, with its range of county/district-level, locally-led projects, ended in 1999. This research seeks to discover how much is remembered about these organisations and their work, and to find out where - in their absence - influence now lies in relation to rural policy unrelated to agriculture.

\footnotetext{
${ }^{1}$ The CRC's focus was on research and the identification and dissemination of good practice relating to disadvantage (Morris 2015).

${ }^{2}$ Its reports and policy papers have been archived:

http://webarchive.nationalarchives.gov.uk/20140321182606/http:/defra.gov.uk/crc/
} 
The present research, which is exploratory, stems from the writer's opinion that the loss of these organisations' influence and work must eventually affect both policy and practice. However, such effects are likely to be slow to materialise and easy to miss. To avoid this, the rural policy landscape must be monitored, especially in relation to topics such as transport, housing and poverty (Morris 2015). ${ }^{3}$ It is hoped that this research will contribute to the debate.

\section{Background}

For many years policies relating to transport, health and housing, for example, were dominated by urban concerns and priorities, leading some academics to characterise rural policy as "a minor adjunct of agricultural policy" (Marsden et al. 1996, p. 42). The risks associated with this approach for some of the people who live in rural England were recognised in two government white papers (DETR/MAFF 2000, Ch. 1; DoE/MAFF 1995, p. 8); and led to the development, adoption and monitoring of, 'rural proofing' (Defra 2017), described by Lloyd et al. as "the main mechanism used by government to ensure that rural needs and circumstances are taken into account in policy development and programme delivery" (Lloyd et al. 2006, p. 5).

Government guidance in relation to rural proofing (Defra 2013) was reviewed in 2015 (Cameron 2015, p. 9). The review concluded that departmental ministers wished "to strengthen their approaches to rural proofing" (p. 22), but did little to suggest that proofing plays a uniformly central role in policy development. Indeed, it noted that "where departments had limited engagement with Defra the result has been a distinct lack of rural proofing activity" (p. 22).

This is concerning for several reasons: first, because government initially committed to rural-proof departmental policies in 2000 (DETR/MAFF 2000, p. 159); second, because of the loss of the expertise of the Rural Communities Policy Unit (RCPU); and third, because of continuing cuts to local authority budgets (Innes and Tetlow 2015).

Gone are the days of rural white papers and the CRC's predecessors, such as the Countryside Agency (CA). The CA, with its focus on integrated rural development, was, according to one school of thought, “...to some extent a quasi-governmental counter to the representations of groups such as the Countryside Alliance" (Woods 2008, p. 269). In other words, the CA provided a voice for those not represented by the Countryside Alliance ${ }^{4}$ and the traditional 'insider' organisations, the Country Land and Business Association (CLA) and the National Farmers' Union (NFU); as well as, for example, the Campaign to Protect Rural England (CPRE) and charities such as the National Trust (Morris 2015).

\footnotetext{
3 The writer worked for the Rural Development Commission (RDC), CA and CRC. He served as a parish councillor and a primary and secondary school governor. $\mathrm{He}$ is an Honorary Research Associate at the University of Exeter, and a visiting lecturer in social policy at Bournemouth University.

${ }^{4}$ The Countryside Alliance was formed in 1997, partly as a response to the then British government's decision to ban hunting with dogs, but also to contribute to the debate about rural needs (Morris 2015, p. 42).
} 
This is not to denigrate these organisations. The remits of the CRC and its predecessors were, however, not sectoral. They represented to government the interests and concerns of people not represented by lobby bodies, and one of the many parts of rural England of interest to them was West Dorset, the area chosen for this research for the reasons explained below.

\section{The research area - West Dorset}

West Dorset, a local authority area in the south west of England, was chosen for two reasons. The first is pragmatic: the writer has lived and worked in the district since 1978, and knows the area well. He has served on two parish councils, and has conducted research locally (Morris 2010, 2003, 2000). Secondly, the area has been the subject of much practical and academic work. For example, the Somerset and Dorset Joint Industries Committee met frequently between 1950 and 1967 to discuss how best to implement local and Development Commission ${ }^{5}$ (DC) policies (County Committee 1967). Strategies for supporting small businesses and promoting economic development were developed in the 1970s and 80s (Council for Small Industries in Rural Areas, n.d.), and significant parts of the county were designated rural development areas (RDAs) between 1984 and 2000, with West Dorset the largest. Between 1994 and 1998, approximately $£ 2.5 \mathrm{~m}$ was invested annually in the RDA (Moseley and Clark 1998). This stimulated work on: housing (Tetlow et al. 1996, p. 46); tourism (Rural Development Commission 1996); transport (Mulroy 1998; Homan-Berry et al. 2002); services (Avanti 1999, Smith 1992, Jackson and Earley 2010); and training (Errington and Farrant 1998).

West Dorset was also the subject of a study by Michael Woods as a prelude to his investigation into the influence of elites in rural Somerset (Woods 1997a, 1997b). He investigated the links between members of the West Dorset establishment, membership of social, professional and political organisations, and the roles played in the local state (Woods 1993). Although this research is not about the establishment per se, Woods' conclusion that members are "generally male, Conservative and landowning" (p. 29), is pertinent, given that, twenty years after Woods' research, Dorset county and district councillors, mainly Conservatives, are $60 \%$ and $69 \%{ }^{6}$ male, respectively. ${ }^{7}$ His finding that "rural England is not an 'apolitical backwater' but an arena of significant political activity" (Woods 1997a, p. 302) is similarly pertinent, as it was informed by his West Dorset study. Approximately $70 \%$ of the district's housing stock is owner-occupied. Public and private sector rented accommodation each account for about 14\% of the total (Dorset County Council (DCC) 2017). Health/income inequalities are "most apparent in the more rural and isolated areas" (West Dorset

\footnotetext{
${ }^{5}$ The first $20^{\text {th }}$ century English rural quango, operational between 1909-1988 (Rogers 1999, pp.130-136).

${ }^{6}$ See www.dorsetforyou.gov.uk/councillors

${ }^{7}$ Approximately $60 \%$ of county councillors are Conservatives (coincidentally, $60 \%$ of county councillors representing West Dorset divisions are also Conservatives); and 69\% of West Dorset's wards are held by Conservative councillors.
} 
District Council 2015, p. 9), and "barriers to housing and essential services are significant"8 (DCC 2015, p. 1).

The area's population is a little over than $100,000^{9}$ and more than $95 \%$ white British, with $29.4 \%$ aged over 65. There are 42 West Dorset district councillors, ${ }^{10}$ and 11 county councillors with divisions in the district. Furthermore, the Conservative Party's control of both local and central government makes for a coherent, mutually supportive and easy-to-understand approach to policy development.

To summarise, the district is of interest because, like many rural areas, it is a place of contrasts; typical in many ways of much of rural England. For these reasons, therefore, and because its character, geography and history - and some of its people and organisations and their work - are familiar to the writer, West Dorset is considered an appropriate study area for this research.

\section{Methodology}

Two methods were used to gather data: an online survey ${ }^{11}$ and ten face-to-face interviews with councillors and local authority and voluntary sector officials. Three types of data were gathered, between November 2015 and December 2016: yes-no answers, rank order responses, and free text contributions.

The yes-no and rank order questions were designed to determine the extent to which organisations and institutions were recognised, and to gain an insight into their perceived influence. The free text survey questions were used to gather participants' views about aspects of rural life. They were also used to steer the interviews. The questions are presented, slightly amended, in Table 1.

Table 1: Questions asked in online survey

\begin{tabular}{|c|c|c|}
\hline Topic & Questions & $\begin{array}{l}\text { Question } \\
\text { type }\end{array}$ \\
\hline $\begin{array}{c}\text { Quango } \\
\text { awareness }\end{array}$ & Have you heard of the quangos listed? & Yes-no \\
\hline Problems & $\begin{array}{l}\text { Although people who live in rural areas benefit from the beauty and relative } \\
\text { tranquillity associated with life in the countryside, some rural dwellers face } \\
\text { particular problems in relation to... well, what exactly? Are there any real } \\
\text { problems, and, if so, what are they? }\end{array}$ & Free text \\
\hline \multirow[b]{2}{*}{$\begin{array}{l}\text { Loci of } \\
\text { influence }\end{array}$} & $\begin{array}{l}\text { Which organisations (public, private, lobby/interest, or charitable) and/or } \\
\text { individuals do you believe influence, or help determine, policy in West Dorset? }\end{array}$ & Free text \\
\hline & $\begin{array}{l}\text { How much influence do the organisations, individuals, groups and office holders } \\
\text { listed below have in West Dorset? In other words, to what extent do you think } \\
\text { they affect life in the district in terms of their influence over rural policy, } \\
\text { government and governance, and/or their power, be it transparent or 'behind the } \\
\text { scenes'? }\end{array}$ & $\begin{array}{l}\text { Rank order } \\
\text { (i.e. one } \\
\text { selection for } \\
\text { each option) }\end{array}$ \\
\hline
\end{tabular}

\footnotetext{
${ }^{8}$ Twenty-one of West Dorset's neighbourhoods are in the $20 \%$ most deprived nationally.

${ }^{9}$ The total population of West Dorset is 101,380. Source: 2016 Mid Year Estimates, Office for National Statistics

10 Thirty Conservative and twelve Liberal Democrat.

${ }^{11}$ Using www.onlinesurveys.ac.uk
} 
The data was analysed conventionally, apart from the use of a 'word cloud' program ${ }^{12}$ to identify the main concerns within the free text. The program was instructed to recognise and merge similar words ('council' and 'councils', for example), and count the number of times the words appear. The survey respondents' answers were merged into a document, loaded into the program, and the word frequencies, in rank order, displayed.

This approach provided a summary of the participants' opinions in relation to problems and influence. It was a useful starting point for the analysis of participants' free text answers, and the interviewees' more wide-ranging, less constrained contributions. These are discussed below.

\section{The participants}

Participants numbered 76, and their locations are illustrated in Figure 1. Information about them, including their self-defined (sometimes multiple) occupations, are presented in Tables 2 to 4 .

Figure 1: Map illustrating the 76 participants' locations

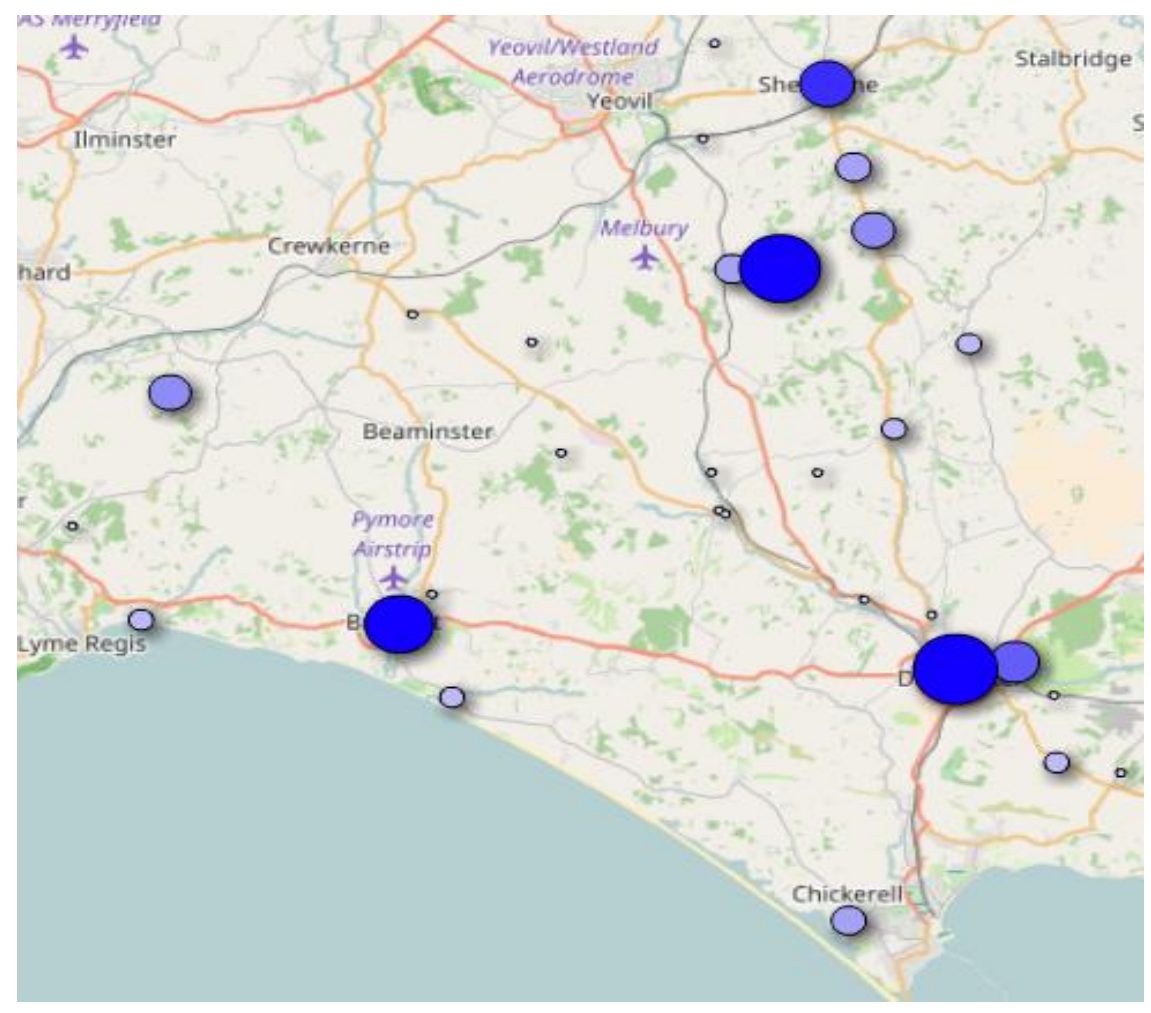

Note: The size of the 'blobs' gives an indication of the relative numbers of participants in given locations.

Eleven people were asked if they would be interviewed (Table 2). Only one, a landowner, failed to reply to the request. Invitations were also sent, by email or letter, to individuals and representatives of organisations associated with the district. These, together with their responses - if any - are detailed in Table 3.

\footnotetext{
${ }^{12}$ Using http://tagcrowd.com
} 
Table 2: Interviewees

\begin{tabular}{|l|c|c|}
\hline & Participated & $\begin{array}{c}\text { Asked to } \\
\text { participate }\end{array}$ \\
\hline Councillors (town, district and county) & 4 & 4 \\
\hline Local government officer & 1 & 1 \\
\hline Town/parish clerk & 1 & 1 \\
\hline Community development worker/officer & 2 & 2 \\
\hline Local partnership officer & 1 & 1 \\
\hline Farmer/landowner & 1 & 2 \\
\hline
\end{tabular}

Table 3: Other organisations/individuals asked to participate ${ }^{13}$

\begin{tabular}{|l|c|c|}
\hline & Participated & $\begin{array}{c}\text { Asked to } \\
\text { participate }\end{array}$ \\
\hline The Countryside Alliance (CAll) & 0 & 1 \\
\hline The Country Land and Business Association (CLA) & 0 & 1 \\
\hline The National Farmers' Union (NFU) & 0 & 1 \\
\hline Campaign for the Protection of Rural England (CPRE) & 1 & 1 \\
\hline Member of Parliament & $0^{14}$ & 1 \\
\hline Member of the European Parliament & 015 & 11 \\
\hline Lord Lieutenancy & 116 & 1 \\
\hline Dorset Association of Parish and Town Councils (DAPTC) & 0 & 1 \\
\hline Dorset Local Enterprise Partnership (DLEP) & 018 & 2 \\
\hline Dorset Agenda 21 (sustainable development organisation) & 0 & 1 \\
\hline Local area partnerships & 1 & 1 \\
\hline Older people's organisation & 0 & 1 \\
\hline
\end{tabular}

The online questionnaire was emailed to West Dorset's town and parish clerks, and district and county councillors. They were asked to participate, and encouraged to invite others - clerks' parish councillors, for example - to take part.

The district's county councillors were asked to participate. Three (two Conservatives and one Liberal Democrat) did so: two via the online survey, one as an interviewee. Fifteen of the 42 district councillors participated: 12 via the online survey, three as interviewees.

\footnotetext{
${ }^{13}$ Although no official from the CAll or CLA participated, one contributor to the survey self-recorded as a member of the CAll, CLA and CPRE.

${ }^{14}$ The MP replied to say that his policy is not to take part in survey work.

${ }^{15}$ One MEP replied asking to be kept informed, but did not participate.

16 The Lord Lieutenant was happy for his vice and deputy lieutenants to be interviewed, on the understanding that their involvement would be personal and non-political.

${ }^{17}$ DAPTC's CEO had only been in post for a few weeks and so, understandably, was unable to contribute.

${ }^{18}$ DLEP's director kindly circulated the invitation within the organisation, but none of the participants indicated any direct affiliation with DLEP.
} 
In total, four councillors were interviewed. One serves on all three tiers of local government, one on two tiers, and two on a single tier.

Residents of the writer's village, selected primarily for their lack of connection with government/politics, and professional contacts living and/or working in West Dorset, were also emailed and asked to contribute, and to invite others to take part.

In all 78 online survey forms were completed by 76 people (two respondents participated twice ${ }^{19}$ ).

Eleven of the survey respondents declined to give their names. Of those who did, 27 are known to the writer, in either a personal or professional capacity. Therefore, 49 (approximately 64\% of the total) are not known to the writer.

As illustrated in Table 4, and as expected, councillors and clerks predominate. The next largest category - residents - is also as expected. To an extent, the latter category results from the writer's personal invitations, but it also reflects the fact that all participants are residents, although not all categorised themselves as such. Several people self-categorised with multiple terms; for example, "[I am a] councillor, resident, churchwarden, farmer" (each term is included in Table 4). The number of clerks and councillors, past and present, from all tiers of local government who contributed represent a large collective pool of knowledge and experience, as do the local government and voluntary sector officials. It is reasonable to assume their collective views reflect reality, albeit a reality skewed towards older age groups. Nevertheless, they deserve consideration.

Participants tended to be middle-aged and older, with professional backgrounds. Attempts were made to persuade young(er) people known to the writer to participate, but to no avail. The writer encouraged farming acquaintances, as well as others, to take part, by means of repeated reminders, but with limited success. ${ }^{20}$ Nevertheless, the distribution of participants (Figure 1) and their occupational mix (Table 4) broadly reflect West Dorset's demographic, and enable inferences to be drawn.

\footnotetext{
19 Their answers were similar. Two differences were recorded by one participant in relation to quango recognition; full agreement by the other. There was less agreement in relation to the influence questions: 22 out of 38 answers in one case (i.e. $~ 58 \%$ matching answers); 28 out of 42 in the other ( $67 \%)$.

${ }^{20}$ One farmer, having looked at the online questionnaire, replied, "When I looked at it I decided that it was not applicable to our situation." A councillor, declining to take part, wrote, "I would be pleased to answer some of this survey but as the first few questions don't apply to me I can't complete the questionnaire. In truth, I don't think that this kind or quango mean very little to the people I represent but pleased to discuss further" (sic). The writer replied, but heard no more. Invitees with non-farming and council backgrounds were also quite difficult to persuade, although pester power eventually resulted in some success.
} 
Table 4: Online survey participant information

\begin{tabular}{|c|c|c|c|}
\hline $\begin{array}{l}\text { Participants' self-defined occupations } \\
\text { (56\% male, } 44 \% \text { female approximately) }\end{array}$ & Participants & $\begin{array}{c}\text { Number } \\
\text { asked to take } \\
\text { part }\end{array}$ & \\
\hline Councillor (all tiers) & $25^{21}$ & $49^{22}$ & \multirow{25}{*}{ 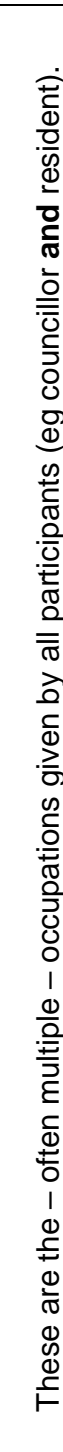 } \\
\hline Town/parish council and parish meeting clerks ${ }^{23}$ & 20 & 52 & \\
\hline Priest & 2 & 2 & \\
\hline Council officer & 1 & 1 & \\
\hline Landowner & 1 & 2 & \\
\hline Retired councillor & 3 & & \\
\hline Resident & 21 & & \\
\hline Retired & 9 & & \\
\hline Businessperson & 5 & & \\
\hline Consultant & 2 & & \\
\hline Farmer & 2 & & \\
\hline Rural property agent & 1 & & \\
\hline Chairman, parish meeting & 1 & & \\
\hline Churchwarden & 1 & & \\
\hline Higher education lecturer & 1 & & \\
\hline Teacher & 1 & & \\
\hline General practitioner & 1 & & \\
\hline Building developer & 1 & & \\
\hline Fundraiser & 1 & & \\
\hline Member of local CPRE group & 1 & & \\
\hline Town planner & 1 & & \\
\hline Parochial church council member & 1 & & \\
\hline District CAll representative & 1 & & \\
\hline Chartered engineer & 1 & & \\
\hline Local CLA representative & 1 & & \\
\hline
\end{tabular}

\section{Participants' views}

In this section the interviewees' and online survey respondents' contributions are presented and discussed. Before considering their views about the problems experienced in rural areas, and the loci of influence in West Dorset, the extent to which the CRC and its predecessor quangos are

\footnotetext{
${ }^{21}$ Of the 25 , six are members of more than one authority (e.g. they serve as both town and district councillors).

${ }^{22}$ There is no direct correspondence between the 49 county and district councillors to whom emails were sent, and the 25 contributors to the online survey who gave their status as councillor. This is because some of the latter are parish councillors; unlike the county and district councillors, they were not specifically asked to participate, but were - presumably - invited to take part by their clerks.

${ }^{23}$ In all, six town and 58 parish councils, and five parish meetings, were asked to participate. Of these, 17 email addresses were not valid. Therefore, 52 bodies received the invitation to participate. Eight respondents gave their position as clerks; it is assumed that the others were councillors or members of parish meetings.
} 
remembered is explored. The number of participants who had heard of the seven quangos that operated in West Dorset between 1909 and 2013 is indicated in Figure 2.

The relationship between the number of years since the organisations closed, their 'localness' in terms of their day-to-day connection with West Dorset, and the extent to which they are remembered is broadly as expected. The four organisations that operated locally in the relatively recent past Countryside Commission (CoCo), RDC, CA and SWRDA - are remembered by most. As the DC and the Council for Small Industries in Rural Areas (CoSIRA), ${ }^{24}$ both of which were involved in rural development work before they were merged to form the RDC (Rogers 1999, p. 111), closed nearly 30 years ago, the relatively low level of recognition is also to be expected.

The low level of recognition of the CRC probably reflects its remit as an adviser to central government, its focus on research rather than grant-supported local action, its small size, its lack of local/regional staff, and its early death on the "bonfire of quangos" (Gash et al. 2010, p. 10).

Figure 2: Participants' awareness of existence of quangos, and years since quangos closed

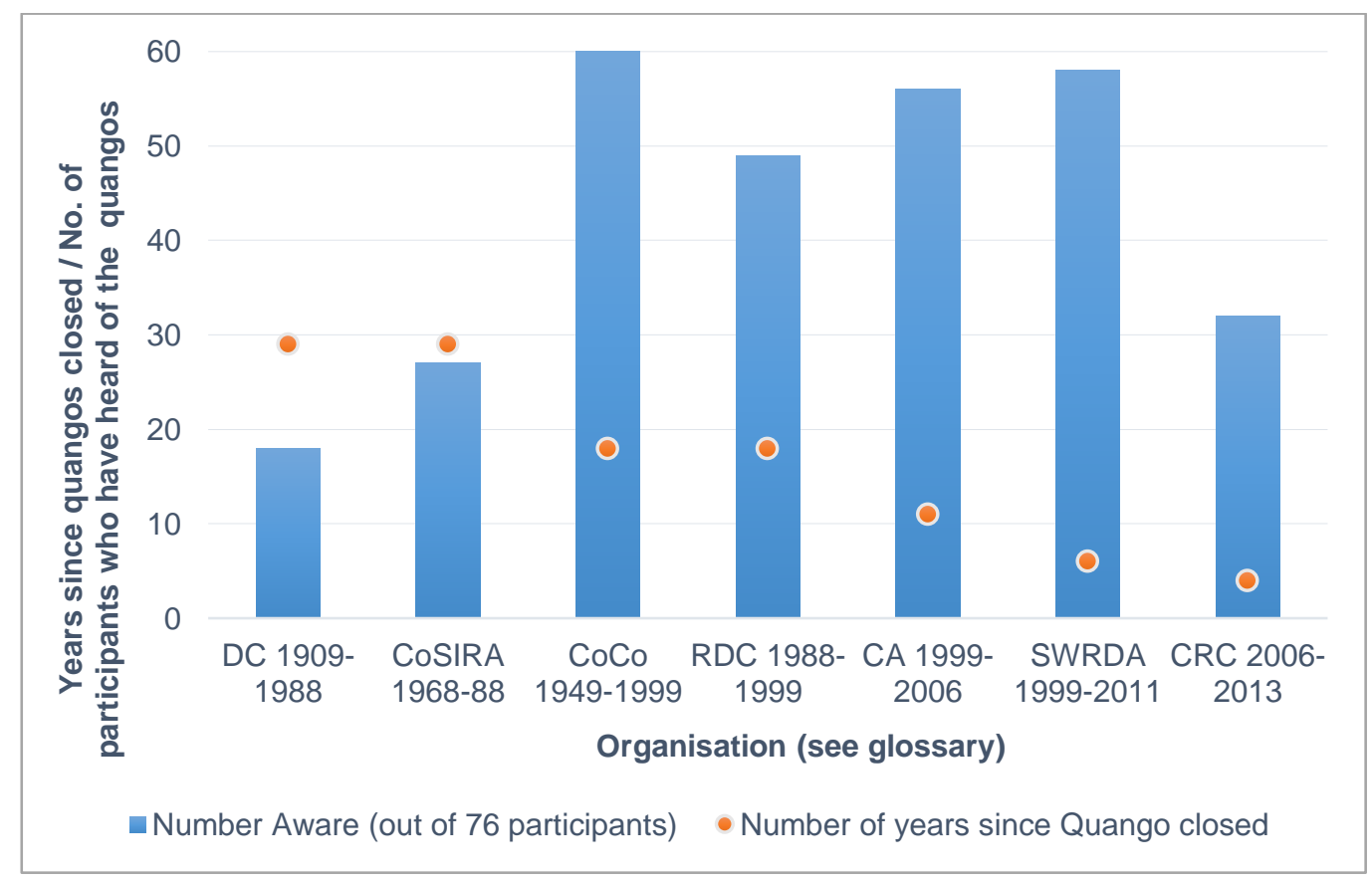

The data suggest that the more physically remote organisations are from 'work on the ground', and the more years that have passed since their closure, the lower the awareness. This logic is likely to apply to their work and achievements. The implications of the findings are twofold: less work will be done, and any value of the work done by these organisations, be it practical or academic, may disappear from institutional and individual memories (Morris 2014, p. 80).

24 CoSIRA's predecessor body, the Rural Industries Bureau (1922-1968), was not included because its operational years lay within those of the DC (Rogers 1999, pp. 131-136). It is thought that if people do not remember the DC, it is unlikely they will remember the Rural Industries Bureau. 
The danger, given these organisations' roles as repositories and disseminators of information, is that knowledge, experience, and useful practice will be lost. Any such losses must represent poor value for the money invested over many years, especially given that the problems identified by the participants, and discussed next, are familiar and likely to persist, before one day being tackled anew.

The main problems identified are public transport, service accessibility, and housing. They were numerically dominant in the 'word cloud' (57, 47 and 46 mentions respectively). These topics disproportionately affect the poor, the un- and under-employed, the elderly, the isolated, and the young (Jackson and Earley 2010; Cloke et al. 1994, Ch. 9; Rogers 1989; Green 1971, p. 95).

Transport was mentioned by 55 of the 76 survey respondents, and eight of the interviewees. One interviewee (councillor) noted:

Well, transport's... always been a problem, but there's less of it now, and I've got a feeling that, with local authorities under pressure to save more money... [there was once] the opportunity to travel by public transport and that isn't here any more, you've got to own a car.

This view was reinforced by a local authority officer, who said, “...we are seeing pressure on... bus services... leading to a reduction in services...".

These views reflect facts. In 2014-2015, Dorset was one of the areas to suffer most in terms of bus service withdrawals, reductions or alterations, with obvious implications for the people who depend(ed) on these services (Wilson 2017, p. 23). Recently, DCC has announced plans to reduce services further (Hogger 2017). This, which helps explain the pressures on the poor (Wilson 2017, p. 19), was recognised by the landowner interviewee, who said, “...transport, bus network... is being cut back all the time... clearly stops mobility for those who haven't got cars", and noted that "obviously, the cutbacks in local authorities... are having a profound impact”.

Closely allied to these comments are those about service accessibility, with one parish clerk stating that "West Dorset is in the bottom 1\% in the country for access to services". ${ }^{25}$ Although many respondents simply stated "access to services" as a concern, others (residents, consultants, a retired education inspector, business person, a fundraiser, a cleric, a GP, a lecturer, clerks, and councillors past and present) were specific, mentioning for example health, libraries, emergency services, shops, post offices, pubs, youth services, sufficiently fast broadband, and garages.

Similar comments were made about the lack of genuinely affordable housing ${ }^{26}$ for those on low incomes who need to rent, or who want to buy. One interviewee, reflecting on how things have

\footnotetext{
${ }^{25}$ The local plan states: “...some parts [of the district] are in the top $1 \%$ of areas in the country that are most inaccessible to services" (WDDC 2015, p. 8).

${ }^{26}$ As opposed to the government's contested definition of affordable rent: “...up to $80 \%$ of a normal market rent" (Mathiason 2015).
} 
changed during more than 20 years of living and working in West Dorset, said, "To some extent the extremities have got worse in relation to the ratio between earnings and house prices". This view was supported by most respondents, whose concerns included "properties expensive to buy or rent" (former district councillor, teacher); a lack of "affordable house prices for born and bred youngsters" (parish clerk); second home ownership (district/town councillor), and the inability of their children to buy a house locally (village resident).

These concerns reflect the problems identified in the district council's local plan, with more than 3,000 people on the housing register (WDDC 2015, p. 8). However, the plan also notes that $91 \%$ of people living in the district are "satisfied with their local area as a place to live" (p. 7); a reflection of both the high quality of life experienced by most of the population, and the hidden nature of rural disadvantage $^{27}$ (Commission for Rural Communitees 2006b, p. 198). Although one interviewee, a district councillor, commented, "People say to me they're very happy with their health service, particularly GPs", this could change if reported reductions in the number of surgery locations proves to be true (Hogger 2016).

Other topics raised include: the cost of - and necessity for - neighbourhood plans (a clerk); the ignorance of incomers in relation to the way the "countryside works" and the importance of country sports $^{28}$ (property agent); the state of the roads (councillor); employment and sexual discrimination (lecturer); fly-tipping and unlawful land occupation by travellers (businessperson); limited employment and education opportunities (councillor, town planner); shops catering mainly for tourists (personal assistant); and approaches that take no account of local distinctiveness (councillor/retired teacher).

A Dorset-based community development worker sensed a lack of representation; that people feel they have no 'voice'. The following comments about local government hint at possible reasons for this: local government is "unimaginative and bureaucratic" (resident); its "expenditure... has been cut to the bone and... is... eating into basic service provision..." (research and policy consultant); and “... parish councils are limited in their authority... too low-level to deliver effective democratic deliberative processes... co-opted and self-serving... [and] ...need to be removed as the lowest level... and a higher level tier introduced" (resident and consultant).

The problems were identified by most participants. Nevertheless, as discussed in the next section, participants believe that WDDC has the most influence over policy.

\footnotetext{
${ }^{27}$ A point reflected by a resident who wrote, "I believe the issue of rural poverty is real, hidden and ignored".

28 This was the only comment about country sports and a lack of understanding about country ways. This perhaps reflects the "twentieth-century ... 'urbanization of the mind", (Rogers 1989, p. 103).
} 


\section{Loci of influence over policy}

In seeking to establish where participants felt influence over policy was located, two sets of data were gathered: free text, and rank order placings in relation to a list of 41 organisations and individuals (42 were listed, as DCA was unintentionally included twice, producing contrasting, rather than contradictory, answers - discussed below). The free text question allowed respondents to explain their choices and reasons without ranking influence. It preceded the rank order question, ensuring that respondents were not influenced by the options listed.

Although respondents were not forced to make rank order selections, most did, creating an overall order of significance (for example, the significance of DCC relative to WDDC).

The two sets are presented separately, following which points of interest from both are drawn out and discussed. First, the free text answers.

The initial analysis using the word cloud program revealed the most frequently used words: council (65 occurrences), Dorset (37), government (26) and district (25). This is to be expected, given the number of councillors and clerks who participated, and the research emphasis on policy. Other sources of influence mentioned included: parish (15), business (12), landowners (9) and developers (7).

Naturally, participants' comments reflect this rank order. Considerable importance is attached to county and district councils. For example, a parish clerk wrote:

The main influence on policy... is [DCC] which itself is constrained by the national government. [WDDC] and environmental agencies... and major environmental pressure groups also have some influence, but parish councils have very little or negligible effect on policy.

Not everyone was so definite. An interviewee, a councillor with many years' experience on county, district and parish councils, paused for fully ten seconds ${ }^{29}$ before answering:

I should have notice of a question like that... It's one of those things where you wonder whether anyone has influence... Lots of individuals have influence... so you come across these individuals... High Sheriff or Lord Lieutenant... and you think, well, how do these people emerge out of the woodwork...? ...It's the great and the good, isn't it?... a network... of people who've got influence, not necessarily power... and nobody actually understands the process by which they emerge.

A local government official said that although local authorities have a leading, but limited, role in formulating policy, national government is increasingly looking for a "stamp of approval" from the Dorset Local Enterprise Partnership (DLEP). Interestingly however, despite DLEP's supposed importance, only three survey respondents and two interviewees mentioned it. ${ }^{30}$

\footnotetext{
${ }^{29}$ This is an exact time, taken from the interview recording.

${ }^{30}$ The official said that DLEP's priority is economic growth. As this is easier to achieve in the conurbation than rural areas, efforts are reportedly being made to mitigate possible consequential detrimental effects for West Dorset.
} 
A company director (semi-retired) suspected that, in addition to large employers and councils, landowners influence policy. Others also mentioned landowners/landowning families ${ }^{31}$ (councillor, priest, company director, resident, teacher, ex-parish council chair, parish meeting chairman). Similarly, given its prominence as both a landowner and developer of the Poundbury development, ${ }^{32}$ the Duchy of Cornwall is mentioned (two councillors, one resident). An interviewee (landowner) said that, in addition to councils, the CLA and DLEP have influence and are "very much working together" (the latter's rural group includes two CLA members, and representatives of environmental and tourism groups).

There were other views. These are summarised in Table 5. Some are contentious, although hardly new. They include, for example, hidden influencers such as freemasons and landowners, and hint at the, "traditional rural establishment" (Woods 2005, p. 54). Also mentioned are private sector/business lobby groups, including chambers of commerce, which exist to make their cases in the public sphere, and developers, a somewhat negative term in the opinion of some participants, with suggestions of behind-the-scenes influence over planning committees. Charities, the young and the elderly are listed, together with the Post Office, Dorset County Hospital Trust, the NHS at the regional level, the Clinical Commissioning Groups (CCG), and Sport England. CPRE is mentioned, both for its "sterling work" (councillor), and its NIMBY ${ }^{33}$ reputation (resident).

This list is indicative of the ubiquity and complexity of governance ${ }^{34}$ as the default approach to government, involving many organisations, including unelected bodies, whose influence may be minimal, but in terms of participants' perceptions real. Belief in hidden influencers is unsurprising, given the diffuse nature of influence in rural England, with class, land, wealth, demography, the economy and rural-urban tensions historically intrinsic (Milbourne 2011; Moseley 2011, Marsden et al. 1996, Ch. 8; Newby 1985).

The above analysis suggests people believe influence is dispersed beyond the formal norms of the democratic process, and is applied, overtly and covertly, by - for example - public-private-voluntary sector partnerships, hidden and visible lobbyists, and influential landowners. The impression given is one of a lack of clarity, and this not least among those involved in the policy processes: the fact that four clerks and four councillors are among the $19.7 \%$ of “don't knows" is revealing.

\footnotetext{
${ }^{31}$ One resident wrote, "I was told recently that 'six families' control Dorset."

${ }^{32} \mathrm{http}: / /$ duchyofcornwall.org/poundbury.html

33 The Oxford English Dictionary defines NYMBY as " a person who objects to the siting of something perceived as unpleasant or hazardous in their own neighbourhood, especially while raising no such objections to similar developments elsewhere."

${ }^{34}$ See Winter (2006, p. 748) for an illuminating illustration of governance complexity.
} 
Table 5: Participants' beliefs as to the loci of influence in West Dorset

\begin{tabular}{|c|c|}
\hline Loci of influence (participants' words) & Participants \\
\hline “Don't know” & $\begin{array}{l}4 \text { clerks, } 4 \text { councillors, } 3 \\
\text { residents, } 1 \text { priest, } 1 \text { farmer } \\
\text { fundraiser, } 1 \text { director }{ }^{35}\end{array}$ \\
\hline "Wessex Water, major environmental pressure groups" & Parish clerk \\
\hline $\begin{array}{l}\text { "Councillors, senior council and government agency employees, local members of } \\
\text { Conservative Party, DAPTC, POPP, DLEP, charities, housing associations" }\end{array}$ & $\begin{array}{l}\text { Former district } \\
\text { councillor }\end{array}$ \\
\hline $\begin{array}{l}\text { "Area of Outstanding Natural Beauty committee/officers, employer organisations, } \\
\text { development agencies, Environment Agency" }\end{array}$ & Parish councillor \\
\hline $\begin{array}{l}\text { "Conservative Party through control of WDDC and DCC - supported by } \\
\text { homeowners, the elderly, landowners/farmers and probably most small business } \\
\text { owners" }\end{array}$ & Resident \\
\hline $\begin{array}{l}\text { "Conservative caucus in WDDC; the CCG; Dorset County Hospital Trust; NHS } \\
\text { England's Wessex Region; DCC senior officers; chambers of trade; HM } \\
\text { Government/Treasury (through financial allocations); MP; NIMBY lobby groups such } \\
\text { as CPRE; business and landowning leaders" }\end{array}$ & Resident \\
\hline "County and district council, and police and crime commissioner" & $\begin{array}{l}\text { Chartered engineer and } \\
\text { councillor }\end{array}$ \\
\hline "Chamber of Trade, Tourism Association, Freemasons, landed gentry, MP, Forces" & Lecturer \\
\hline $\begin{array}{l}\text { "Conservative Party (dominates local politics at county and district levels), large } \\
\text { developers, large landowners, WDDC" }\end{array}$ & $\begin{array}{l}\text { Resident and former } \\
\text { chair of parish council }\end{array}$ \\
\hline $\begin{array}{l}\text { "... not based on any factual evidence, but suspect that quangos exert minimal } \\
\text { influence and that landowners, large employers and councils have a greater } \\
\text { influence and impact on policy" }\end{array}$ & Semi-retired director \\
\hline $\begin{array}{l}\text { "Council officers whose decisions are rubber-stamped by councillors - neither are in } \\
\text { touch with local needs" }\end{array}$ & Business person \\
\hline "Tourism organisations and departments" & $\begin{array}{l}\text { Business person } \\
\text { (Hotelier) }\end{array}$ \\
\hline $\begin{array}{l}\text { "Political parties; NFU and CLA - both could be more vocal; the church should be } \\
\text { more involved as interest and pressure group" }\end{array}$ & Resident \\
\hline $\begin{array}{l}\text { "Council finance directors based on what they are told/given by central government } \\
\text { and by developers in the private sector" }\end{array}$ & District councillor \\
\hline $\begin{array}{l}\text { "Parish, district and county councils; young people by deciding where to live and } \\
\text { work; older people requiring peaceful surroundings and help" }\end{array}$ & $\begin{array}{l}\text { Councillor (district and } \\
\text { county) }\end{array}$ \\
\hline $\begin{array}{l}\text { "HM Government, the NHS, local government; the now-private business of the Post } \\
\text { Office and other private businesses" }\end{array}$ & Resident \\
\hline $\begin{array}{l}\text { "The CCG, Freemasons (which have a role in the planning process); farmers and } \\
\text { their lobbying organisations; wealthy landowners, retirees, owners of significant- } \\
\text { sized businesses (there are plenty of pension and trust fund managers here. A visit } \\
\text { to the president's tent at the Melplash Show was very revealing); county council } \\
\text { officers; our MP has been a huge influence over the demise of local services and } \\
\text { 'big government' through policymaking nationally" }\end{array}$ & Councillor \\
\hline $\begin{array}{l}\text { "Central government; WDDC and in a small way, parish councils; landowners - as a } \\
\text { lot of these represent the same sort of politics it makes it hard for diverse } \\
\text { communities to flourish in an inclusive way as the people making decisions have a } \\
\text { vested interest in keeping the area exclusive to other people who share their views } \\
\text { and values" }\end{array}$ & Resident and teacher \\
\hline $\begin{array}{l}\text { "Central government, and to lesser extent (and getting lesser) the EU, local } \\
\text { government, at every level. Significant: lobby groups include NFU, CLA; interest } \\
\text { groups include Natural England, RSPB, Sport England" }\end{array}$ & Town planner \\
\hline
\end{tabular}

${ }^{35}$ These participants comprise $19.7 \%$ of the total respondents. 
When the data obtained from the rank order question is analysed, however, a seemingly clearer picture emerges. This data is presented in Figures 3-8 under six headings: government, main political parties, business, charities/professional bodies, rural organisations, and 'county'. These are discussed below.

Figure 3 (government) indicates that WDDC, central government, DCC, councillors and the MP are believed to have most influence. This is relative, in that only the two councils and central government 'score' more than 50\%. Others more closely reflect free text views, including, interestingly in view of the current debate around Brexit, ${ }^{36}$ that whilst EU was seen to have some influence, MEPs have relatively little influence. Similarly DLEP, parish councillors, EA and NE are believed to have little influence.

Figure 3: Participants' assessment of loci of influence over rural policy in West Dorset 'government'

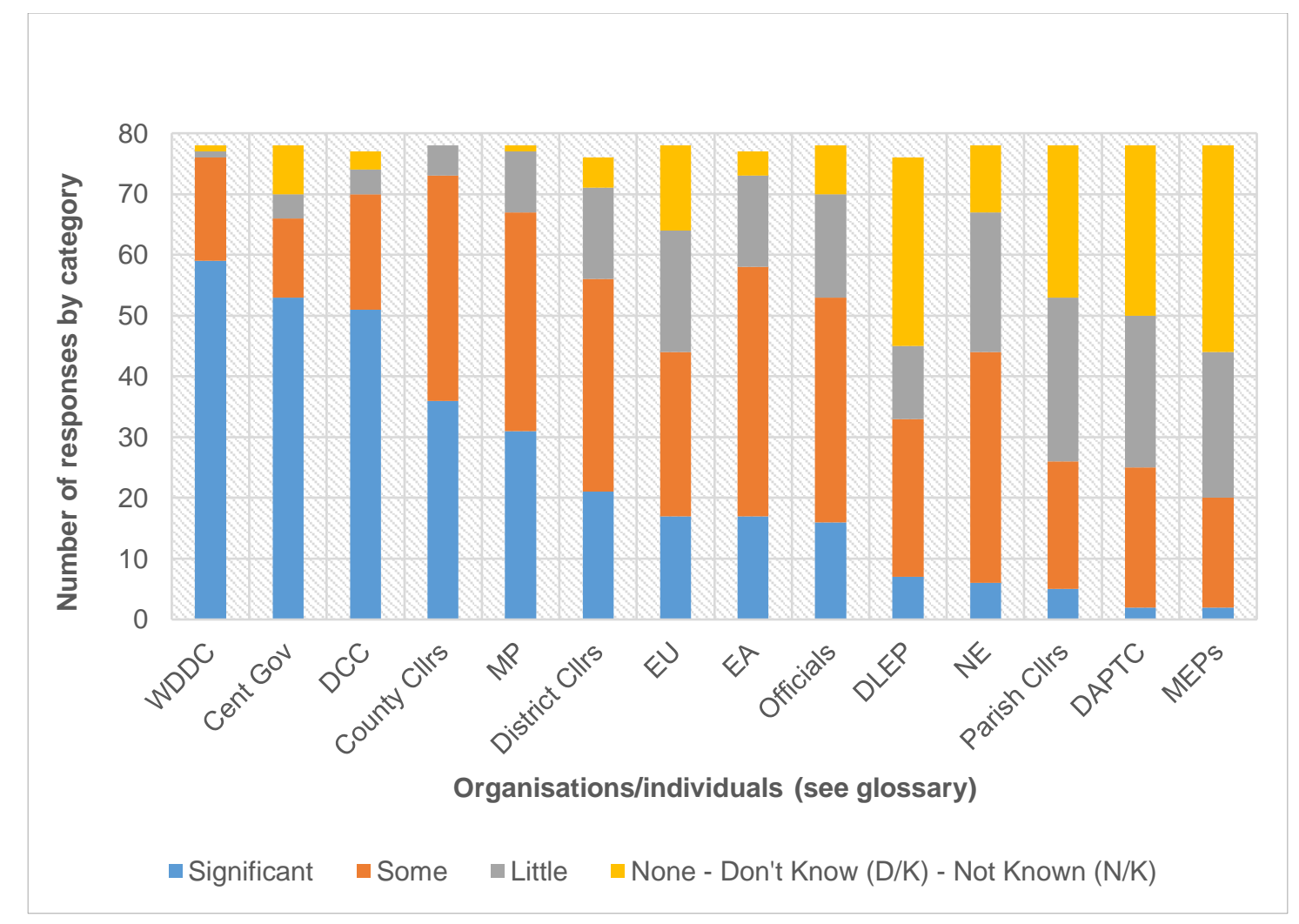

Turning to political parties, the degree of influence respondents accord to them (Figure 4) reflects the long-standing dominance of the Conservative Party in Dorset, ${ }^{37}$ although the Liberal Democrat candidates have been a close second at each election since 1997.

The influence of the Labour Party is thought to be negligible (there are no Labour DCC or WDDC councillors).

\footnotetext{
${ }^{36}$ The shorthand term for the UK's June 2016 decision to leave the European Union.

${ }^{37}$ The constituency has returned Conservative/Unionist MPs, several from county landowning families, since 1885 .
} 
Figure 4: Participants' assessments of loci of influence over rural policy in West Dorset 'main political parties'

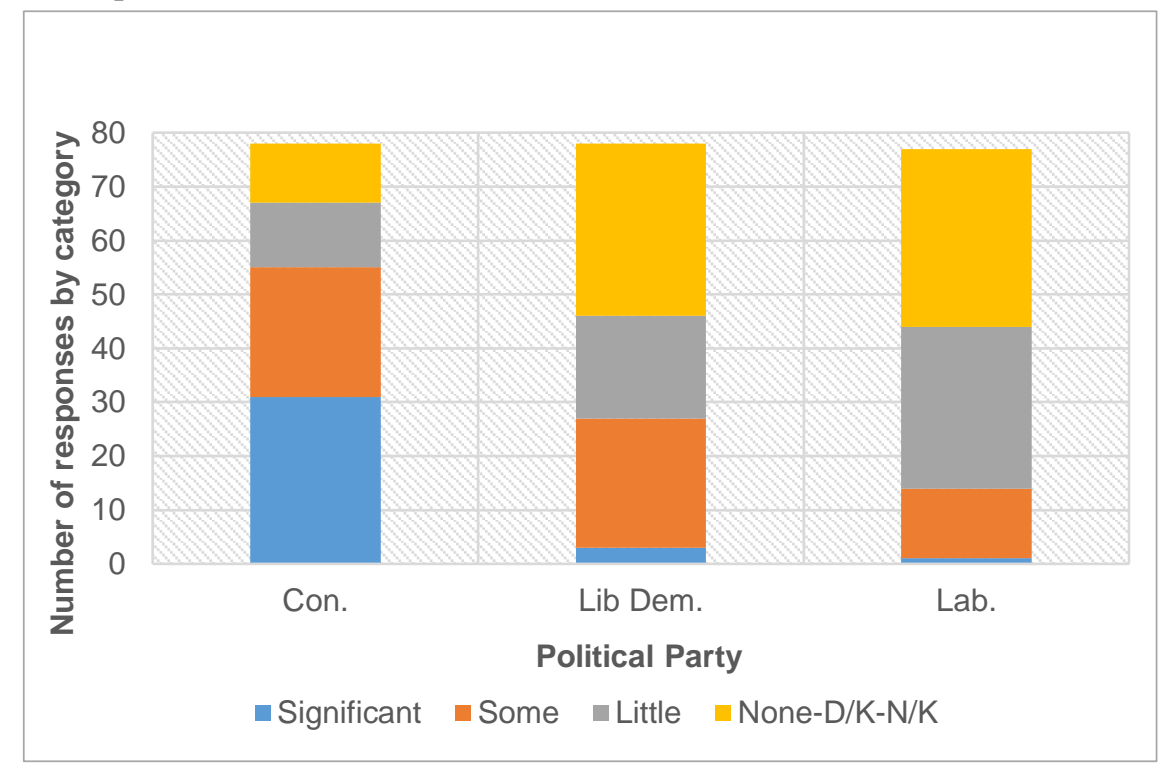

Unfortunately, the writer failed to include UKIP in the list of parties. However, although UKIP won $12.5 \%$ of the vote in the 2015 general election, ${ }^{38}$ no respondent or interviewee mentioned it. This is an interesting omission by both writer and participants. It reflects, perhaps, UKIP's relatively recent arrival in West Dorset (the first candidate stood in 1997, and the party has only once polled more than 3,000 votes).

In relation to 'business' (Figure 5), the free text answers suggest a degree of influence. Specific mentions were made of pension and trust fund managers (councillor), and private business and business leaders (two residents). The rank order data, however, suggests otherwise. The relative strength of the Institute of Directors (IoD) and the Confederation of British Industry (CBI), although clearly weak in absolute terms, perhaps reflects West Dorset's character, and the possible dominance of the ten businesses (DCC 2017) that employ more than 250 people. As most (85\%) of West Dorset's nearly 6,000 businesses employ fewer than ten people (DCC 2013, p. 15) the direct influence on policy of either group, but especially the latter, is likely to be minimal; as is membership of business leaders' organisations and trade unions.

\footnotetext{
${ }^{38} \mathrm{http}: / /$ www.bbc.co.uk/news/politics/constituencies/E14001031
} 
Figure 5: Participants' assessments of loci of influence over rural policy in West Dorset 'business'

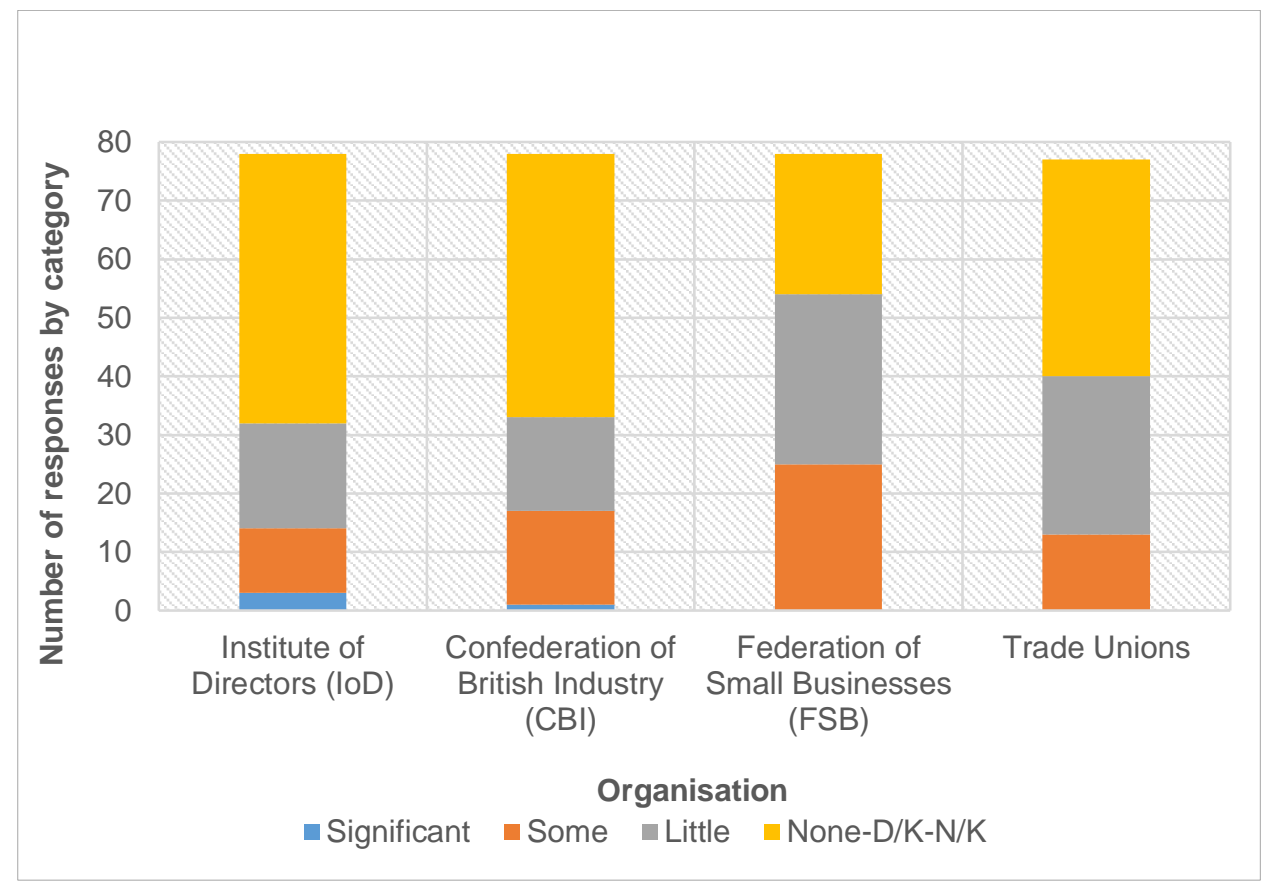

In similar vein to the business sector, professional and charitable organisations (Figure 6) are perceived to have relatively little or no local influence.

Figure 6: Participants' assessments of loci of influence over rural policy in West Dorset 'charities/professional bodies'

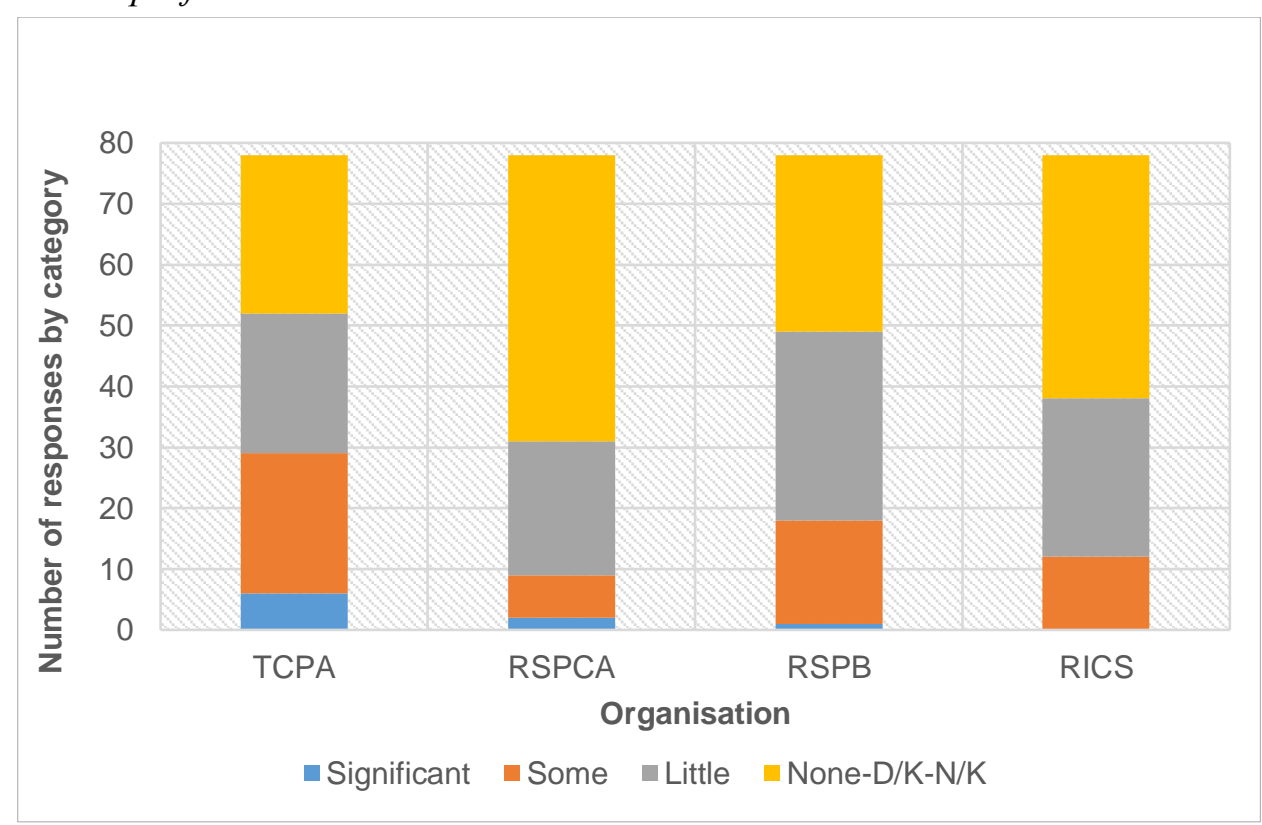

Within the grouping categorised as 'rural', estates and farmers are believed to be influential (Figure 7). When viewed in isolation the degree of significance is not great. However, when the influence of those with land interests is aggregated (estates, farmers, NFU, CLA, CAll, and, perhaps, CPRE and 
DWT), the combined level of significance is much greater. While it cannot be taken as read that these categories have fully aligned interests, they have shared interests in what happens on, to, and control of, the land, and so some degree of commonality can perhaps be assumed.

Figure 7: Participants' assessments of the loci of influence over rural policy in West Dorset 'rural'

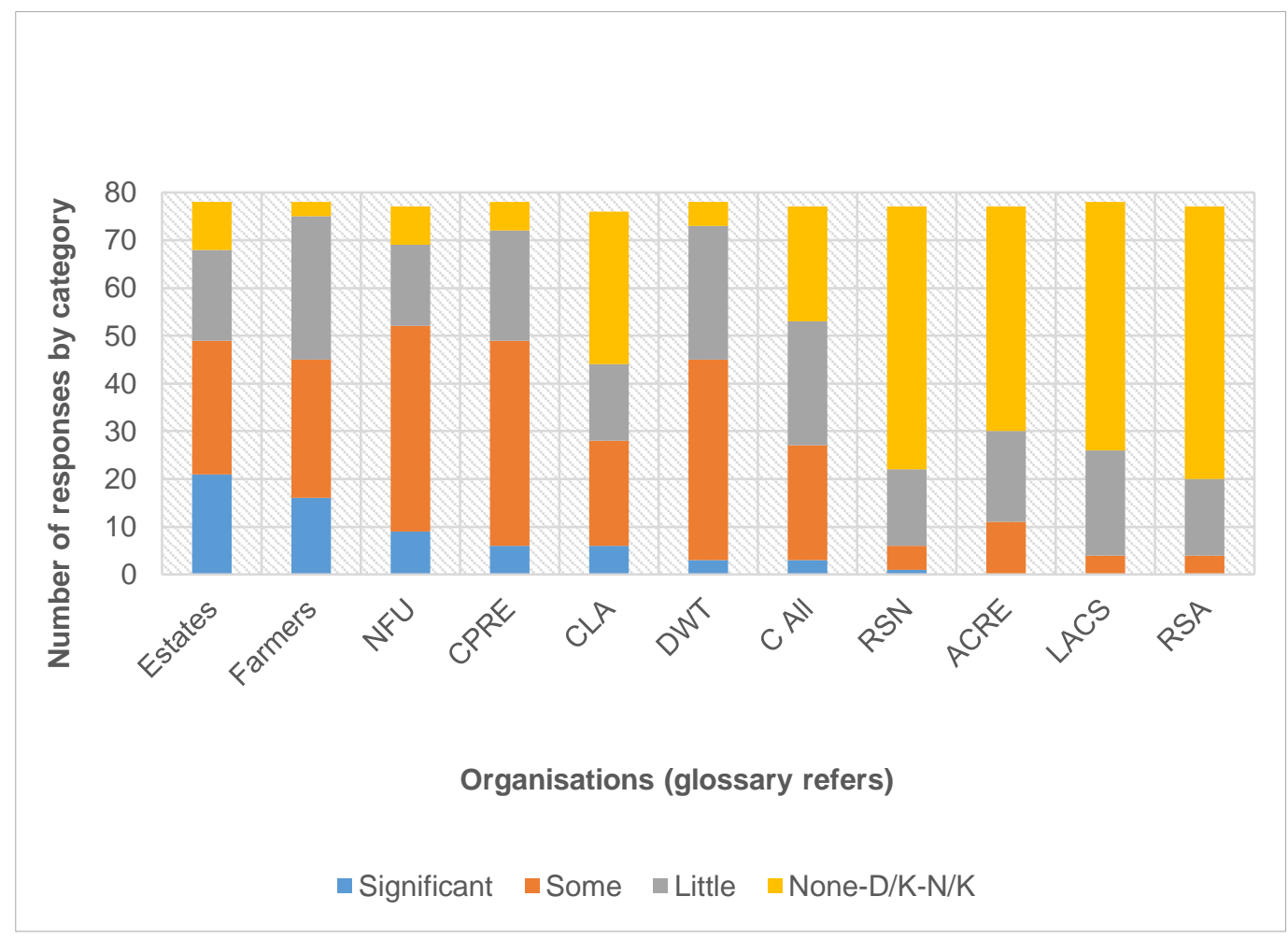

The 'county' categories, NIMBYs, the WI, the Lieutenancy and the Shrievalty (Figure 8) are also thought to have little influence.

Figure 8: Participants' assessments of loci of influence over rural policy in West Dorset 'county'

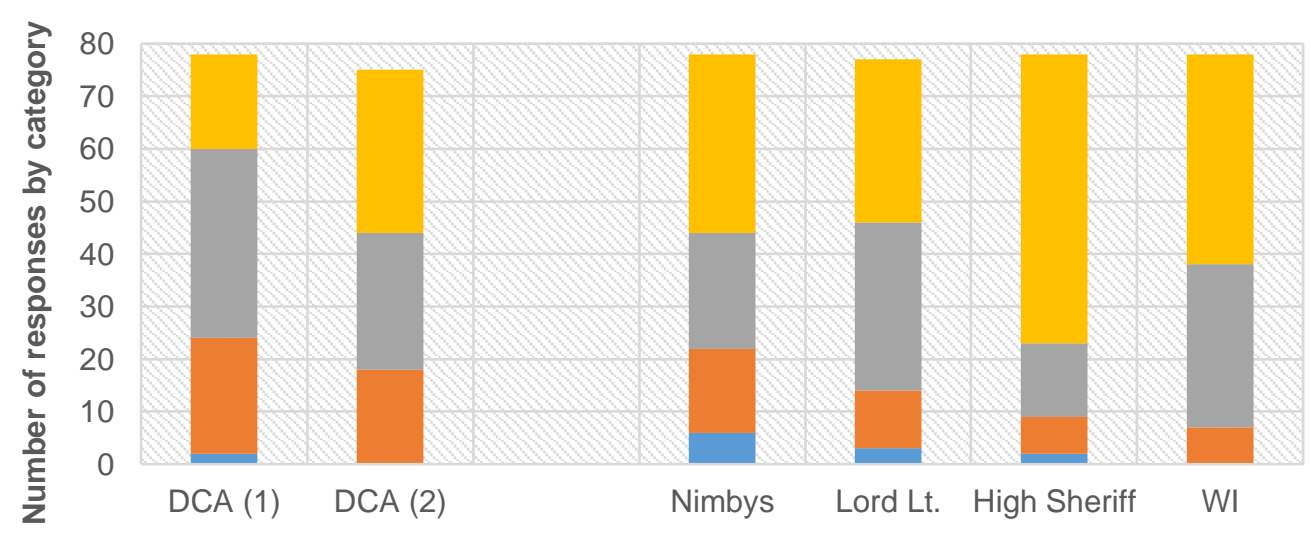

Organisations and individuals (glossary refers)

-Significant $\quad$ Some $\quad$ Little $\quad$ None-D/K-N/K 
The results for DCA, inadvertently included twice in the survey, illustrate the difficulties associated with interpreting survey results. The weights given to each significance category for DCA are similar, the most notable difference being the greater number allocated to 'some significance' by participants when first asked to rate DCA (recorded as 'DCA1'). In neither case, however, do participants believe that DCA has much influence over policy.

When considered overall, particularly in relation to central and local government and the Conservative Party, none of the organisations and individuals listed in Figures 3-8 have absolute influence over policy. However, party politically in West Dorset, Conservative influence predominates (Figures 3 and 4).

However, the rank order answers should not necessarily be taken at face value. They are blunt and singular, in that only one rank could be allocated to each option. Similarly, the free text question asked respondents simply to list sources of influence. These, while informative and relevant, are limited by their discreteness. They cannot account for the - largely hidden - influence exerted by the elite professional, social, personal and family networks explored by Woods and mentioned earlier (2005, pp. 54-83). This is discussed next.

\section{Discussion}

The free text and rank order submissions suggest that influence over policy lies primarily with elected representatives within the Conservative-dominated district and county councils. However, as illustrated in Table 5, respondents also refer to NIMBYs and homeowners, those middle-class 'incomers' whose post-war growth in influence was noted by Pahl (1965, p. 9), Newby (1985, pp.164-172), and Woods (2005, pp. 186-187).

The middle classes, a significant demographic, tend to dominate local government as officers and elected members, and so have a visible influence.

Respondents also mentioned landowners, the landed estates, and farming families, all historically influential. A glance through the lists of past members of the Lieutenancy ${ }^{39}$ and Shrievalty ${ }^{40}$ reveals landowning families who have, across the centuries, occupied both positions, held senior roles in local government as Conservatives, and provided Conservative MPs.

To an extent these traditional centres of influence persist. For example, the county's current Lord Lieutenant was the Conservative Leader of DCC and North Dorset District Council. He is a landowner, as are the High Sheriff and the current Leader of DCC. The High Sheriff, whose mother held the position in 1979, is also a deputy lieutenant. The Leader of DCC is also a district councillor,

\footnotetext{
${ }^{39} \mathrm{https} / / /$ en.wikipedia.org/wiki/Lord_Lieutenant_of_Dorset

${ }^{40}$ https://en.wikipedia.org/wiki/High_Sheriff_of_Dorset
} 
and a past leader of WDDC. He, like the Leader of DCC, is a Conservative. The Vice Lieutenant and several deputy lieutenants are farmers/landowners; others have had very senior positions in the county and beyond. ${ }^{41}$ Also, as detailed in this research, several councillors sit on all three tiers of local government, and so cut across organisational boundaries. These people's paths cross as part of their day-to-day work.

As members of professional, semi-social ${ }^{42}$ and social networks, they might not know one another well, but, as discussed by Savage (2015, Ch. 4), there is strength and influence to be gained from such 'weak ties' (pp. 132-133).

In view of this, influence over policy is likely to be more nuanced than the results of this research suggest. The district has long been, and remains, in terms of its polity and establishment, essentially conservative, and also politically Conservative. This is not to suggest that West Dorset is a hotbed of corruption or inefficiency. ${ }^{43}$ It is simply to recognise the potential for - or perhaps inevitability of the patronage, recruitment and influence, if not power, identified by Woods (2005, pp. 81-83).

Indeed, significant power is the one thing that does not lie at the local level. It is well known that the UK government is strongly centralised (Local Government Association 2017, p. 4; Morris and Nichols 2007, p. 32); for, as Crewe (2016) states, "Of every $£ 1$ raised in taxation, 91 pence is controlled and allocated by central government. The austerity programme pursued since 2010 has thrown into relief the vast power differential between central and local government." Nevertheless, although power in financial terms lies with central government, central government's ability strategically to influence policy is limited by rural England's heterogeneity.

Whitehall departmentalism is another limiting factor. For example, responsibilities for the rural economy, transport and housing are dispersed between Defra, the Department for Transport and the Department for Communities and Local Government. This, no doubt, explains Lord Cameron's call for an "upscaling" of rural-proofing expertise within departments, following the closure of the CRC (Cameron 2015, p. 22), and the absorption of the RCPU, established in 2011 to "lead rural proofing and act as a centre for rural expertise", into Defra's rural policy team ${ }^{44}$ ( p. 8).

\footnotetext{
${ }^{41} \mathrm{https}: / / \mathrm{www}$.dorsetforyou.gov.uk/lieutenancy/vice-lord-lieutenant

${ }^{42}$ I use semi-social to refer to a network where people meet for professional reasons and develop social ties (eg councillors from across parties who attend joint meetings of, eg, outside bodies, or social events with links to their work - to an extent they are exclusive). It is where people collaborate and develop links though, eg, joint working even though their day-to-day political standpoints might be very different.

${ }^{43}$ Nevertheless, reports for the - not disinterested - Electoral Reform Society point to the dangers of singleparty domination (Fazekas 2015), and argue for a move to proportional representation in the interests of better democracy (Baston and Linton 2015).

${ }^{44}$ https://www.gov.uk/government/groups/rural-communities-policy-unit
} 
This paper argues that in this confused and confusing relationship between the local and the centre we seem to have the worst of both worlds.

Local government has long been the target of central government cuts (Laffin 2016, p. 365). Although powers appear on occasions to have been devolved, they fall more into the American notion of "shift-and-shaft federalism" than any form of democracy-improving blessing (2016, p. 368). As the burden of centrally-imposed austerity increasingly affects the provision of services to the detriment of the old, the young and the poor, local government's only - forced - choice is to restructure and reduce annual spending. Between 2016/17 and 2019/20 central government's support to Dorset's councils will be reduced by $£ 52 \mathrm{~m}$ between $2016 / 17$ and 2019/20 (total spending in 2016/17 was £920m). ${ }^{45}$ The resulting cuts to budgets and services inevitably reduce councillors' influence.

The views of the participants about influence are ambiguous. Their free text contributions suggest an opaque landscape, whereas the rank order answers appear to suggest that influence clearly lies with government. The reality might, as this paper suggests, be more complicated, with influence spread more widely via traditional and elite/establishment networks. In any event, matters are unclear; for, as a councillor who has served for many years on all tiers of local government, and who worked in the sector professionally, noted: "I think elected councillors have got virtually no influence".

This suggests that more, wider, research is needed. For example, the views of those involved in government beyond West Dorset - such as Local Government Association officials, academics, civil servants, politicians and their advisers - could offer a broader perspective. Whether that would provide more clarity is a moot point, however, given the tensions between local and central government (UK Parliament 2014, para. 10).

Finally, in relation to the CRC, given the complications associated with constant change and attacks on local democracy, the loss of the CRC's and its predecessors' work is unlikely to be noticed. The answer to the question, has the CRC been missed, is unsurprisingly, but disappointingly, "I don't know". Perhaps it is too soon to say. However, as only three participants, all officials once involved with the CRC's and the other quangos' work, mentioned the CRC in any detail, knowledge of its activities appears to be minimal.

It may be impossible ever to discern the effects of the CRC's closure on rural policy and related work. There are too many variables: economic and demographic changes locally and nationally; loss of institutional memory as time passes and councillors, officers and others move on; and the structural changes discussed above. The data in Table 1 revealed that fewer than $35 \%$ of respondents

\footnotetext{
${ }^{45}$ Between 2010/11 and 2019/20, Dorset’s councils will have needed to reduce spending by nearly $£ 200 \mathrm{~m}$ (http://tinyurl.com/zp15xoq).
} 
remembered the DC and CoSIRA 30 years after they were closed. It seems likely, therefore, that in 2043 few will remember the CRC, let alone its achievements.

In 2010 Geoffrey Lean, the Daily Telegraph's environment correspondent, said that the CRC's abolition would make life harder for the rural poor, and asked, "Who will speak for the countryside?" (Lean 2010) (6 $^{-}$a view supported by The Guardian's correspondent (Hetherington 2013). Nearly seven years on, with the RCPU disbanded, the answer from within government appears to be 'no one'.

Outside government, the Rural Services Network (RSN) and its affiliates, together with voluntary sector organisations, continue to represent 'the rural'. Their resources, however, are small, and their influence at the local level, to judge from this research, negligible. Nevertheless, the RSN did persuade the government to increase significantly the rural delivery grant (RSN 2017); no small achievement.

Meanwhile, rural policy appears to have narrowed. Parliamentary debates emphasise small businesses, broadband, farming, fishing and forestry (Potton et al. 2017; Hansard 2016), rather than the topics identified by participants in this research.

There has been one recent reference to the CRC, made by the Defra shadow secretary of state: "This Government's abolition of Labour's [CRC] and their establishment of the much-diminished policy unit in its place has weakened rural communities through a lack of both capacity and expertise" (Maskell 2017). This could well be the last reference to the Development Commission's successor. If so, there is a certain symmetry, for the DC's creation in 1909, welcomed by the Labour Party as the most revolutionary measure introduced by a British government, was opposed by the Conservative MP Lord Robert Cecil on the grounds that it was part of a socialist programme (Rogers 1999, p. 9).

It has taken a while, but Cecil's view finally prevailed. It is most unlikely that the present Conservative government will recreate the $\mathrm{CRC}$, not least because no one at the local level seems to have noticed its passing. This does not mean, of course, that the work of the rural quangos will not be missed in relation to future policy development and impact. It is reasonable to posit, therefore, that the policies most affected will be those for which the quangos had some responsibility: housing, transport, and access to services. These, the main topics of concern raised by the people who took part in this research, are those that most affect the poorest and least powerful members of rural society. Plus ça change!

\footnotetext{
${ }^{46}$ Most below-the-line comments were - very - antagonistic. One contributor stated, without supporting evidence, "The parasitic Commission for Rural Communities helped no-one."
} 


\section{Acknowledgements}

First and foremost, I am grateful to the people who took the time to help me with this research. My thanks to the interviewees for agreeing to meet me, for their patience, and for their openness. Similarly, thank you to everyone who completed the lengthy survey form. Your contributions are appreciated.

I also thank Claire Nichols and Dr Daniel Keech for kindly commenting on the paper. Their support and constructive criticism did much to boost the confidence of this lone researcher!

As ever, any mistakes or omissions are mine, and mine alone.

\section{Declaration of conflicting interest}

The author declared no potential conflicts of interest with respect to the research, authorship, and/or publication of this article.

\section{Funding}

The author received no financial support for the research, authorship, and/or publication of this article.

\section{References}

Avanti, C. (1999) Dorset rural services \& social housing report, trends \& issues 1998/99. Dorchester, Dorset, UK: Dorset Community Action.

Baston, L. and Linton. M. (2015) Changing the political map of Britain. Kingston, London. Available at: https://makemyvotecount.files.wordpress.com/2015/09/er-book-v-6-web.pdf

Cameron, E. (2015) Independent rural proofing implementation review. London: Defra (UK Government).

Cloke, P., Milbourne. P. and Thomas, C. (1994) Lifestyles in rural England. Salisbury, UK: Rural Development Commission.

Commission for Rural Communities. (2006a) Commission for Rural Communities annual report and accounts. London: The Stationery Office.

Commission for Rural Communities. (2006b) Rural disadvantage - reviewing the evidence (CRC 31). London: Commission for Rural Communities.

Council for Small Industries in Rural Areas. (n.d.) County strategy for Dorset. Salisbury: CoSIRA.

County Committee. (1967) Minutes of the Somerset and Dorset Joint Rural Industries Committee. 1950-1967 (held by the writer). Dorchester, Dorset, UK: Development Commission.

Crewe, T. (2016) The strange death of municipal England. London Review of Books, 38 (24), 6-10.

Defra. (2013) Rural proofing guidance. Available at: www.gov.uk/guidance/rural-proofing-guidance [Accessed: 12 January 2017].

Defra. (2017) Rural proofing practical guidance to assess impacts of policies on rural areas. London: Defra (UK Government).

DETR/MAFF. (2000) Our countryside: The future. London, UK: HM Government.

DoE/MAFF. (1995) Rural England, a nation committed to a living countryside. Pub. L. No. Cm 3016. UK: HM Government.

Dorset County Council. (2013) West Dorset economy \& labour market profile. Dorchester: Dorset County Council.

Dorset County Council. (2015) State of Dorset - deprivation. Dorchester, Dorset, UK: Dorset County Council. 
Dorset County Council. (2017) West Dorset area profile - Dorset statistics. Dorset Statistics. Available at: https://apps.geowessex.com/stats/AreaProfiles/District/west-dorset [Accessed: 17 January 2017].

Errington, A. and Farrant, S. (1998) New training inititiatives for rural business - development guides. Plymouth, UK: University of Plymouth.

Fazekas, M. (2015) The cost of one-party councils. London: Electoral Reform Society, London.

Gash, T., Magee, I., Rutter, J. and Smith, N. (2010) Read before burning. London: Institute for Government.

Green, R.J. (1971) Country planning, the future of the rural regions. Manchester: Manchester University Press. https://doi.org/10.1080/00420987220080111

Hansard. (2016) Rural economy - leaving the EU. House of Common. London. Available at: https://hansard.parliament.uk/Commons/2016-11-24/debates/120F71D0-7DD6-4746-BCB1BC4802964877/RuralEconomyLeavingTheEU [Accessed: 4 March 2017].

Hetherington, P. (2013) Who will lead the renaissance for rural communities? The Guardian, 9 April, p. 1.

Hogger, H. (2016) GP surgeries could close and practices to merge in major healthcare shake-up in Weymouth and west Dorset. Dorset Echo. Available at:

www.dorsetecho.co.uk/news/14880804.GP_surgeries_could_close_and_practices_to_merge_in_major_h ealthcare_shake_up_in_Weymouth_and_west_Dorset/ [Accessed: 17 February 2017].

Hogger, H. (2017) Dorset County Council is proposing to reduce number of subsidised bus services from 35 to 7. Bridport \& Lyme Regis News. Available at: www.bridportnews.co.uk/news/15071545._Devastating_impact_of_bus_cuts_that_will_see_subsidised _services_slashed_from_35_to_SEVEN [Äccessed: 17 February 2017].

Homan-Berry, M., Higgins, C., Mitchell, S. and Place, S. (2002) Sherborne and District transport appraisal 2002. Dorchester, Dorset, UK: Dorset Community Action.

Innes, D. and Tetlow, G. (2015) Central cuts, local decision-making: Changes in local government spending and revenues in England, 2009-10 to 2014-15. London: Institute for Fiscal Studies. doi: 978 -1- 90946381 -3. https://doi.org/10.1920/bn.ifs.2015.00166

Jackson, P. and Earley, S. (2010) Findings of the 2009 rural services survey. Dorchester, Dorset, UK.

Laffin, M. (2016) Planning in England: New public management, network governance or post-democracy? International Review of Administrative Sciences, 82 (2), 354-372. https://doi.org/10.1177/0020852315581807

Lean, G. (2010) The countryside will be the poorer. The Daily Telegraph, 2 July, p. 1.

Local Government Association (2017) Growing places: building local public services for the future. London: LGA.

Lloyd, N., Hatcher, J., Cuff, J., Atkinson, D., Thomson, H., Jacobs, L. and Cook, P. (2006) Rural proofing monitoring report. Commission for Rural Communities - challenging government to meet rural needs. London and Cheltenham: Commission for Rural Communities.

Marsden, T., Murdoch, J., Lowe, P., Munton, R. and Flynn, A. (1996) Constructing the countryside. (2nd ed.). London: UCL Press. https://doi.org/10.1177/030913259401800228

Maskell, R. (2017) Leaving the EU: the rural economy. Hansard. Available at: https://hansard.parliament.uk/commons/2017-01-17/debates/BF78EA63-D2E4-405A-ADB1524DA4D5AF37/LeavingTheEUTheRuralEconomy [Accessed: 4th March 2017].

Mathiason, N. (2015) Affordable housing: What is it and just how affordable is it? A Bureau guide. The Bureau of Investigative Journalsim. Available at: https://www.thebureauinvestigates.com/2015/05/29/what-isaffordable-housing-a-bureau-guide/. [Accessed: 17th February 2017].

Milbourne, P. (2011) Rural welfare. In: Curry, N. and Mosely, M. (eds.) A quarter century of change in rural Britain and Europe - Reflections to Mark 25 Years of the Countryside and Community Research Institute. Cheltenham, Gloucestershire, UK: University of Gloucestershire (CCRI).

Morris, G. (2003) 2002, a spatial odyssey an investigation into the sphere(s) of influence of Sherborne, Dorset (an English country town). Seale Hayne: University of Plymouth, UK. 
Morris, G. (2014) What's left, what's been done, and what next? England's 2000 Rural White Paper. Town council activities and a survey of town clerks. Commonwealth Journal of Local Governance, (15), 6185. doi: http://dx.doi.org/10.5130/cjlg.v0i0.4063. https://doi.org/10.5130/cjlg.v0i0.4063

Morris, G. (2015) Who will look after Englands rural disadvantaged now? Commonwealth Journal of Local Governance (16/17), 31-59. doi: http://dx.doi.org/10.5130/cjlg.v0i0.4485. https://doi.org/10.5130/cjlg.v0i0.4485

Morris, G.R. (2000) Rural services. Are you being served? An investigation into changes in service provision in three west Dorset villages between 1953 and 1999. Totnes, UK: University of Plymouth, UK.

Morris, G.R. (2010) People helping people - an assessment of the market towns and related initiatives, and the extent to which they addressed rural poverty. Exeter: University of Exeter, UK.

Morris, G. and Nichols, C. (2007) Strengthening the role of local councillors: An overview of information, strengthening the role of rural councillors: An overview of information, policy and debate. Cheltenham, Gloucestershire, UK.

Moseley, M.J. and Clark, M. (1998) An evaluation of the impact of the Dorset rural development programme, 1994-1998. Cheltenham, Gloucestershire, UK: Cheltenham \& Gloucester College of Higher Education, UK.

Moseley, M. (2011) Rural people and communities. In: Curry, N. and Moseley, M. (eds.) A quarter century of change in rural Britain and Europe - reflections to mark 25 years of the Countryside and Community Research Institute. Gloucester: The Countryside and Community Press.

Mulroy, T. (1998) Lyme Regis traffic study. Birmingham, UK: TPi - The Transportation Consultancy, Birmingham.

Newby, H. (1985) Green \& pleasant land? Social change in rural England. (2nd ed.). London: Wildwood Huse. https://doi.org/10.1016/0309-586x(81)90009-1

Pahl, R.E. (1965) Class and community in English commuter villages. Sociologia Ruralis, 5 (1), 5-23. https://doi.org/10.1111/j.1467-9523.1965.tb00507.x

Potton, E., Garton-Grimwood, G., Booth, L. and Sutherland, N. (2017) Debate pack - effect of the UK leaving the EU on the rural economy. London: House of Commons, UK Government.

Rogers, A. (1989) People in the countryside. In: Mingay, G.E. (ed.) The rural idyll. London: Routledge.

Rogers, A. (1999) The most revolutionary measure. Salisbury, UK: Rural Development Commission.

Rural Development Commission. (1996) The impact of tourism on rural settlements. Salisbury, UK: Rural Development Commission.

Rural Services Network. (2017) Rural fair share campaign. Available at: http://ruralfairshare.org.uk/

Savage, M. (2015) Social class in the 21st century. London: Penguin Random House. https://doi.org/10.1177/0964663917710975a

Smith, D. (1992) Village shops and post offices. Yeovil, UK: Wessex Rural Consultants.

Tetlow, R., Auchincloss, M. and Haddrell, K. (1996) Rural needs in local authority housing strategies. Salisbury, UK: Rural Development Commission.

UK Government. (2013) Commission for Rural Communities has closed. Available at: www.gov.uk/government/organisations/commission-for-rural-communities [Accessed: 25th September 2016].

UK Parliament. (2014) A new Magna Carta? Political and constitutional reform. Available at: www.publications.parliament.uk/pa/cm201415/cmselect/cmpolcon/463/46308.htm [Accessed: 6 July 2017].

West Dorset District Council. (2015) West Dorset, Weymouth \& Portland Local Plan 2011-2013 (adopted October 2015). Dorchester, Dorset, UK: West Dorset District Council.

Wilson, B. (2017) State of rural services 2016. Tavistock, Devon, UK: Rural Services Network.

Winter, M. (2006) Rescaling rurality: Multilevel governance of the agro-food sector. Political Geography, 25 (7), 735-751. https://doi.org/10.1016/j.polgeo.2006.07.001 
Woods, M.J. (1993) Elites in West Dorset. Lampeter: University of Wales.

Woods, M.J. (1997a) Elites in the rural local state Vol. 1. Thesis. University of Bristol.

Woods, M. J. (1997b) Elites in the local rural state Vol. 2. Thesis. University of Bristol.

Woods, M.J. (2005) Contesting rurality. Aldershot, Hampshire, UK: Ashgate Publishing Ltd. https://doi.org/10.4324/9781315259390

Woods, M.J. (2008) New Labour's countryside. Rural policy in Britain since 1997. (Woods, M., ed.). Bristol: The Policy Press. https://doi.org/10.1111/j.1467-9523.2009.00483.x 